\title{
Dieper graven voor effectievere toepassing
}

Citation for published version (APA):

Ruiter, R. A. C. (2014). Dieper graven voor effectievere toepassing. Maastricht University. https://doi.org/10.26481/spe.20141121rr

Document status and date:

Published: 21/11/2014

DOI:

10.26481/spe.20141121rr

Document Version:

Publisher's PDF, also known as Version of record

\section{Please check the document version of this publication:}

- A submitted manuscript is the version of the article upon submission and before peer-review. There can be important differences between the submitted version and the official published version of record.

People interested in the research are advised to contact the author for the final version of the publication, or visit the DOI to the publisher's website.

- The final author version and the galley proof are versions of the publication after peer review.

- The final published version features the final layout of the paper including the volume, issue and page numbers.

Link to publication

\footnotetext{
General rights rights.

- You may freely distribute the URL identifying the publication in the public portal. please follow below link for the End User Agreement:

www.umlib.nl/taverne-license

Take down policy

If you believe that this document breaches copyright please contact us at:

repository@maastrichtuniversity.nl

providing details and we will investigate your claim.
}

Copyright and moral rights for the publications made accessible in the public portal are retained by the authors and/or other copyright owners and it is a condition of accessing publications that users recognise and abide by the legal requirements associated with these

- Users may download and print one copy of any publication from the public portal for the purpose of private study or research.

- You may not further distribute the material or use it for any profit-making activity or commercial gain

If the publication is distributed under the terms of Article $25 \mathrm{fa}$ of the Dutch Copyright Act, indicated by the "Taverne" license above, 


\section{Maastricht University}

\section{Prof. dr. Rob Ruiter}

Faculty of Psychology and Neuroscience

\section{Dieper graven voor effectievere toepassing}

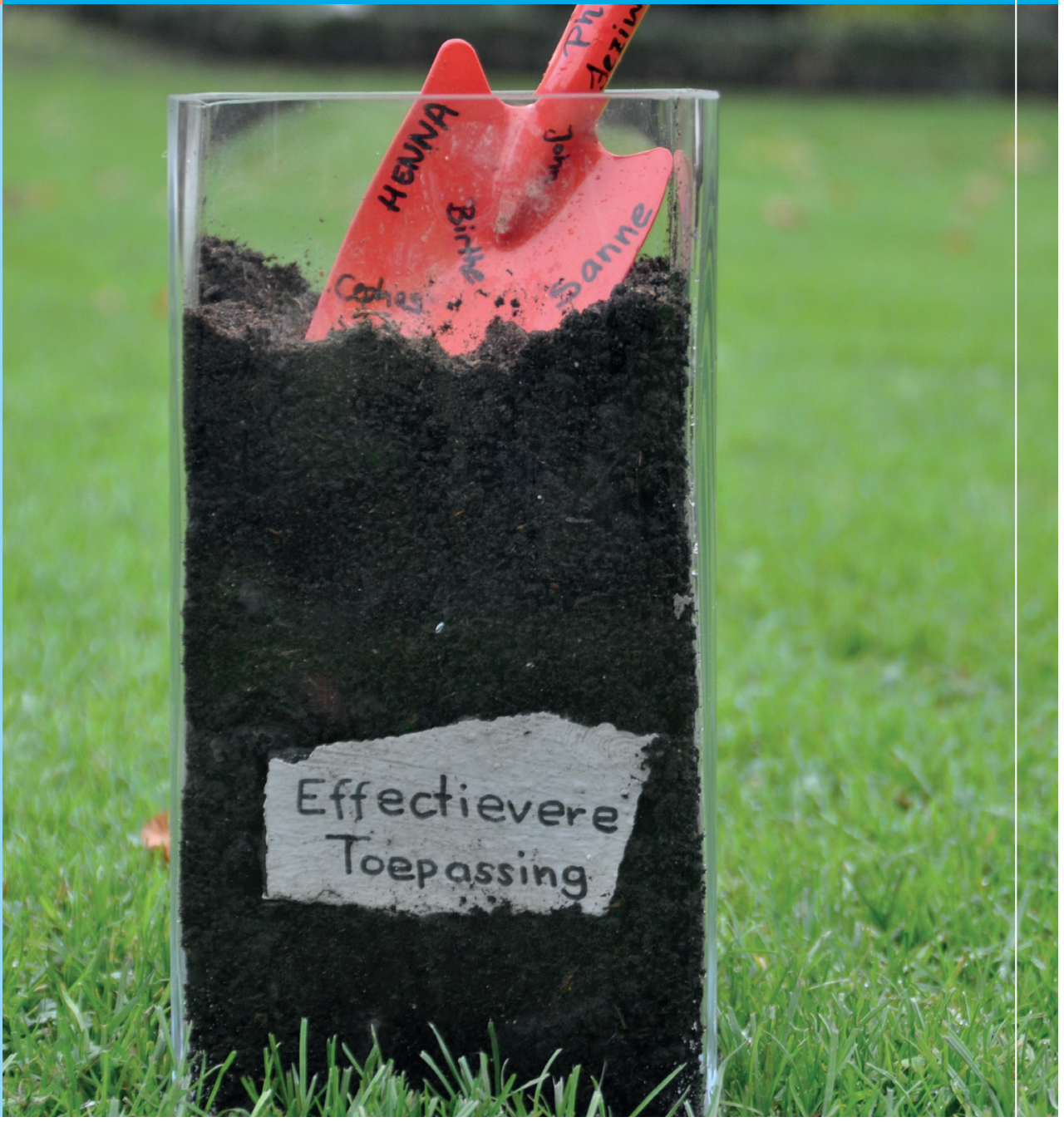


Dieper graven voor

effectievere toepassing 


\section{Colofon}

Design \& print: Canon Business Services, Maastricht

ISBN: 978-90-5681-444-1

NUR: 770

All rights reserved. No part of this publication may be reproduced, modified, stored in a retrieval system or made public without the prior written permission of the author or publisher. 


\section{Dieper graven voor effectievere toepassing}

\section{Inaugurele rede}

In vrije (verkorte) vorm uitgesproken bij de aanvaarding van het ambt van bijzonder hoogleraar Toegepaste Psychologie in het bijzonder de toepassing van de Neurowetenschappen binnen de Sociale Psychologie aan de Faculteit der Psychologie en Neurowetenschappen van de Universiteit Maastricht.

Maastricht, vrijdag 21 november 2014

Prof. dr. R.A.C. Ruiter 
Geachte mijnheer de rector, leden van de commissie van toezicht, hooggeleerde leden van het cortège, beste collega's, lieve vrienden en familie,

\section{Inleiding}

Het betekent veel voor mij dat ik vandaag hier mag staan om mijn ambt als bijzonder hoogleraar te aanvaarden met het uitspreken van een publieke rede. Ze zeggen wel eens dat om carrière te maken in de wetenschap je op meerdere plekken moet hebben gewerkt, het liefst ook aan gerenommeerde internationale universiteiten en onderzoekscentra. Ik ben het daar mee eens. Een kijk in de keuken van een ander kan geen kwaad en zelfs zeer verfrissend werken. In mijn geval is het echter anders gelopen. Ik ben namelijk een kind van deze universiteit, als academicus en wetenschapper hier geboren en getogen, en nooit meer weggegaan. Simpelweg omdat ik het naar mijn zin had en nog steeds erg heb.

In 1988 kwam ik als 18 jarige jongen uit het ver gelegen Twente naar Maastricht, toen nog ruim 3,5 uur in plaats van de nu ruim 2 uur met de auto en, opmerkelijk genoeg, nu nog steeds dezelfde ruime 4 uur met het openbaar vervoer. Ik herinner me nog als de dag van gisteren hoe ik mijn ouders uitzwaaide nadat ze me hadden afgeleverd bij een hospita in Rothem, gemeente Meerssen, waar ik mijn eerste kamer had en rustig kon wennen aan het studentenleven, wel zo veilig vonden mijn ouders, en ik eerlijk gezegd ook wel.

Ik kwam niet om psychologie te studeren, want die opleiding kwam hier pas in 1995, maar voor de studie Gezondheidswetenschappen binnen wat nu heet de Faculty of Health, Medicine and Life Sciences aan deze universiteit. Een ideale studie als je wel iets in het sociaal maatschappelijke veld wilt gaan doen, maar zoals ik niet precies weet wat, en je vele opties open wilt houden.

Gezondheidswetenschappen kende in die tijd 7 studierichtingen, dus keuze zat. Ik koos in eerste instantie voor de richting Beleid en Beheer, maar al snel kwam ik erachter dat mijn belangstelling elders lag, bij het verklaren van het gedrag van mensen. Niet zozeer het abnormale gedrag zoals we dat in de klinische settings van de psychologie tegenkomen, maar het alledaagse, normale gedrag van mensen; Waarom doen 
mensen dingen zoals ze doen? Wat verklaart hun gedrag? Kunnen we dat gedrag beïnvloeden? Die vragen maakten me even aan het twijfelen of ik dan toch niet elders psychologie moest gaan studeren, maar ik had het direct naar mijn zin in het zuiden, in een kleine stad met mooie natuur om me heen en ik had toen al - al zeg ik dat nu met de wijsheid van achteraf - een hart voor de toepassing van kennis.

Ik koos daarom voor de studierichting Gezondheidsvoorlichting, nu gezondheidsbevordering geheten. Die keuze is de bepalende factor geweest voor de reden dat ik hier nu sta. Hoe dat zit, leg ik in de loop van het verhaal op verschillende plekken wel uit. (Een goed verstaander merkt nu trouwens op dat ik na deze rede weliswaar hoogleraar in de psychologie ben, maar feitelijk geen psycholoog ben, maar dit terzijde)

\section{Gedragsverandering}

In de gezondheidsbevordering staat de preventie van ziekte door middel van gedragsverandering centraal. Gedragsverandering is het vakgebied dat ik als mijn expertise beschouw en dat vandaag ook centraal staat in mijn rede.

Als ik het heb over gedragsverandering dan doel ik niet alleen op het ontwerpen van tv-spotjes, affiches, voorlichtingsfoldertjes en websites die ons moeten overtuigen wat wel of niet verstandig is om te doen, maar ik heb het dan over alle activiteiten die we kunnen ondernemen om te stimuleren dat mensen zich op vrijwillige basis 'gezonder' en 'veiliger' gaan gedragen(Green \& Kreuter, 2005). Gedragsverandering is in dit kader meer dan mensen informatie geven over ziekte en gezondheidsrisico's. Bij gedragsverandering moet $u$ ook niet alleen aan voorlichting en educatie denken, gericht op het individu, maar ook aan aanpassingen in de fysieke en sociale omgeving van het individu, bijvoorbeeld door middel van beleid en regel- en wetgeving. Denkt $u$ bijvoorbeeld aan het ingestelde rookverbod voor publieke ruimtes, onlangs herbevestigd voor de ook voor Zuid-Limburg zo typische kleine cafe's om de hoek. Gedrag komt dus niet alleen tot stand op basis van overwegingen en ideeën die we hebben over wat goed en slecht is, op basis van informatie die ons wordt aangereikt, maar wordt in belangrijke mate gestuurd door de context waarin we ons bevinden. Gedrag vindt plaats in een geheel van relaties op interpersoonlijk, sociaal en organisatorisch niveau en binnen nationale en internationale kaders. 
Deze sociale kijk op menselijk gedrag is de essentie van de sociale psychologie. Het wetenschapsgebied dat de basis vormt van mijn onderzoek en van hoe wij hier in Maastricht gedragsverandering benaderen. Sociale psychologie is de wetenschappelijke studie naar hoe menselijk gedrag wordt beïnvloed door de sociale omgeving waarin dat gedrag plaatsvindt (Allport, 1985). Sociaal psychologen verklaren gedrag door te bestuderen hoe gedachten, gevoelens en het gedrag zelf worden beïnvloed door de aanwezigheid van anderen. De aanwezigheid van anderen kan de werkelijke aanwezigheid van anderen zijn (bijvoorbeeld als je samen met vrienden in de voetbalkantine zit en voor jezelf had besloten geen biertje te nemen, maar een cola, en je vervolgens dramatisch faalt ), maar die aanwezigheid van anderen kan ook verbeeld zijn, anderen zijn niet fysiek aanwezig maar je ervaart hun aanwezigheid wel (bijvoorbeeld als je na het behalen van je rijbewijs voor de eerste keer de auto mee mag van je ouders en je dondersgoed weet dat ze er niet op zitten te wachten dat die beschadigd terugkomt).

Sociale psychologie is één van de basisdisciplines in de psychologie. Sociale psychologie is echter niet alleen een basale (of fundamentele) sociale wetenschap die de aard en oorzaken van menselijk gedrag in vernuftige experimenten bestudeert, maar is ook een toegepaste discipline die relevant is voor het bestuderen van allerlei maatschappelijk relevante problemen en vraagstukken. In zijn toegepaste vorm is sociaal psychologisch onderzoek van grote waarde bij het begrijpen van alledaags gedrag en biedt het belangrijke aanknopingspunten voor hoe dat gedrag in de gewenste richting te veranderen. De sociale psychologie is dan ook de basis van allerlei toepassingsgebieden in de psychologie, zoals de gezondheidspsychologie en verkeerspsychologie waarbinnen ik vooral opereer en waar ik me het meest thuis voel. Hoe kunnen we gezondheidswerkers motiveren om zich ieder jaar te laten vaccineren tegen de griep? Wat motiveert zwangere vrouwen in Zambia om de bevalling wel of niet te laten plaatsvinden in een kliniek onder deskundige begeleiding? Hoe kunnen we jongens die net hun rijbewijs hebben gehaald trainen zodat zij wel over de verstandelijke vermogens beschikken om niet de held uit te hangen achter het stuur? Vragen die de basis vormen van mijn onderzoek en dat van mijn collega's binnen de sectie Toegepaste Sociale Psychologie en waarin het begrijpen en veranderen van gedrag centraal staat. 


\section{Probleem- en gedragsanalyse als eerste stappen}

Om gedragsverandering te realiseren is een systematische aanpak gewenst, te beginnen met een grondige analyse van het probleem (Bartholomew, Parcel, Kok, Gottlieb, \& Fernández, 2011; Ruiter, Massar, van Vugt, \& Kok, 2012). Het heeft geen zin aan oplossingen te denken als niet eerst is vastgesteld of het gezondheids- of veiligheidsprobleem, of welk ander probleem dan ook, daadwerkelijk een probleem is. Over het algemeen geldt dat we iets als een relevant probleem beschouwen als dat probleem onze kwaliteit van leven nadelig beïnvloedt. Denk aan de uitbraak van de mazelen in 2013 in bepaalde groepen mensen die hun kind om geloofsredenen of andere overwegingen niet of slechts gedeeltelijk hebben laten vaccineren binnen het Rijksvaccinatieprogramma. Dat bepaalde groepen zich niet laten vaccineren is al langer bekend en is een continue punt van zorg bij de verantwoordelijken voor het Rijksvaccinatieprogramma, maar het probleem kreeg pas echt de volle aandacht van de overheid op het moment dat dit de volksgezondheid in gevaar kan brengen, of de aandacht van de individuele burger op het moment dat de eigen gezondheid of die van naasten wordt bedreigd (ouders die hun kinderen thuis houden van de opvang). Of neem nu de internationale reactie op de ebola epidemie. Streng aan de eigen grenzen, maar pas laat aan de grond in Westelijk Afrika om het probleem bij de kern te bestrijden.

Voor de gedragswetenschapper in mij moet het probleem echter niet alleen maatschappelijk relevant zijn, maar moet menselijk gedrag een belangrijke oorzaak zijn van het probleem en moet gedragsverandering een oplossing kunnen bieden. Een uitgebreide gedragsanalyse is vervolgens van belang waarin de factoren die het ongewenste gedrag aansturen worden beschreven. Wederom, individueel gedrag wordt niet alleen beïnvloed door factoren in het individu zelf (zijn gedachten en gevoelens), maar ook door factoren die buiten hem of haar liggen in de directe of indirecte omgeving van het individu (mening en gedrag van belangrijke anderen, gedragskaders van beleid en regelgeving). Voor deze omgevingscondities zijn individuen en instanties verantwoordelijk wiens beslissingen en gedrag ook weer worden bepaald door persoonsen omgevingsfactoren.

Die persoons- en omgevingsfactoren noemen we determinanten. Pas als we die determinanten kennen, pas dan kunnen we nadenken over mogelijkheden voor interventie (Green \& Kreuter, 2005). 
Even terzijde, het proces dat ik hier beschrijf, eerst het probleem kennen alvorens te werken aan oplossingen, is een logisch proces. Helaas is het niet een dergelijk logisch proces dat het ook altijd als zodanig wordt beoefend in het veld van gedragsverandering. Maar al te vaak worden we geconfronteerd met goed bedoelde initiatieven, waar geen gedegen analyse aan ten grondslag ligt. Bijvoorbeeld in het veld van verkeerseducatie ontstijgt het antwoord van programma-ontwikkelaars op de meest basale vraag 'Wat wil het programma bereiken?' vaak niet het niveau van: "We willen de verkeersveiligheid bevorderen". Welk verkeersveiligheidsprobleem? Welk gedrag ligt eraan ten grondslag? Welke factoren van dat gedrag wil je gaan aanpakken? Hoe dan? Eenvoudige vragen op het eerste gezicht maar waar we vaak geen eenduidig antwoord op krijgen. Dat is jammer, want het wel of niet succesvol zijn van de interventie lijkt dan niet meer dan gebaseerd te zijn op een 'lucky shot'. Ik noem verkeerseducatie, maar dit ontbreken van een goede analyse en dus kennis van het probleem vinden we bij veel gedragsinterventies, ook in andere toepassingsdomeinen.

Kortom, bij gedragsverandering gaat het erom factoren te identificeren en theoretisch goed te kennen om er vervolgens gericht op te kunnen interveniëren (Bartholomew et al., 2011; Kok, Schaalma, Ruiter, \& Van Empelen, \& Burg, 2004; Schaalma \& Kok, 2009). Als je weet dat iemands evaluatie van gedrag in termen van positieve en negatieve opbrengsten, in de sociale psychologie aangeduid als attitude, een belangrijke invloed heeft op gedrag dat je dan een instrument inzet waarvan bekend is dat die attitudes op een effectieve manier kan beïnvloeden. Dat je informatie aanreikt die overtuigend is omdat er argumenten worden gehanteerd die nieuw zijn en als geloofwaardig en persoonlijk relevant worden beschouwd. Dat roken longkanker kan veroorzaken is misschien wel een geloofwaardig argument maar niet bepaald nieuw en door vele rokers of beginnende roker niet op zichzelf van toepassing geacht. Of als je vaardigheden wilt trainen, dat dan meer nodig is dan een Sire campagne waarin verteld wordt dat je "tolerant moet zijn want daar knap je van op". Dan zal je met mensen concreet aan de slag moeten. Hoe dat te doen vergt kennis, zeer specifieke kennis over hoe gedrag tot stand komt, wat tolerant gedrag inhoudt, maar ook over hoe gedrag op een effectieve manier te beïnvloeden: hoe tolerant gedrag op een effectieve manier aan te leren en op een efficiënte manier toe te passen. 
Dat weten hoe gedrag tot stand komt en vervolgens weten hoe dat te beïnvloeden, dát is de expertise die mij aantrok in de keuze voor de studierichting Gezondheidsvoorlichting eind jaren 80 van de vorige eeuw, inderdaad een eeuwigheid geleden. Vandaag de dag is dat nog steeds de essentie en tegelijkertijd de schoonheid van mijn vak: diep graven naar verklaringen van onwenselijk gedrag om vervolgens die kennis op een effectieve manier te kunnen toepassen bij het bevorderen van wenselijk gedrag.

\section{Gedragsverandering als wetenschap}

Gedragsverandering is een op zichzelf staand vakgebied. Ik bedoel daarmee allereerst te zeggen dat gedragsverandering onderscheiden moet worden van gedragsverklaring. In het wetenschappelijk onderzoek binnen de psychologie zijn we vooral bezig met gedragsverklaring. Onderzoekers proberen factoren en processen te identificeren die gedrag aansturen door middel van verschillende typen onderzoek; door te observeren, door te praten met mensen in interviews en groepsdiscussies, door vragenlijsten af te nemen, of door experimentjes met hen te doen waarin getest wordt of specifieke factoren en processen inderdaad het gedrag aansturen.

Gedragsverandering vergt echter meer dan alleen de juiste verklaring. Naast theorieën voor het begrijpen en voorspellen van gedrag, heeft de psychologie ook veel te bieden voor het veranderen van gedrag en gedragsdeterminanten. Zoals één van mijn rolmodellen in de toegepaste psychologie, de helaas veel te vroeg overleden Herman Schaalma, het in zijn inaugurele rede in 2007 beschreef (Schaalma, 2007, p. 18): "De psychologie biedt een groot warenhuis vol met theorieën over gedragsverandering, over onder andere risicocommunicatie, attitudeverandering, het verhogen van zelfvertrouwen, het aanleren van vaardigheden, en over hoe we kunnen bevorderen dat gedragsverandering beklijft." Het is zaak te weten welke theorieën er zijn en in welke gang je die kunt vinden, en dan vervolgens de juiste theorie of in dit geval methodiek van de plank te nemen. Helaas is het namelijk niet zo dat de psychologie voor iedere vraag een pasklaar antwoord heeft. Er zijn talloze theorieën voorhanden, maar ieder probleem, iedere doelgroep en iedere situatie is weer anders en vereist een eigen specifieke benadering waarvoor additioneel onderzoek bijna altijd noodzakelijk is (Buunk \& Vugt, 2013). 
Dit maakt dan ook dat gedragsverandering een wetenschapsgebied is waarvoor specifieke expertise vereist is: succesvolle gedragsverandering houdt in dat theoretische kennis over gedragsverandering bekend is en wordt benut, dat wordt geleerd van eerder onderzoek dat is gedaan op het onderwerp van studie, en bijna altijd, dat eigen onderzoek wordt gedaan onder leden van de doelgroep en bij mensen die de interventie moeten uitvoeren. Ontwikkelaars van gedragsprogramma's hebben dan ook specifieke academische vaardigheden nodig in het kunnen lezen van wetenschappelijke theorieën en onderzoek, en het analyseren en interpreteren van data verkregen uit onderzoek, of die nu kwalitatief (interviews) of kwantitatief (vragenlijsten) van aard zijn.

Gedragsverandering heeft behoefte aan gedragswetenschappers. Een behoefte die gelukkig ook steeds meer verwoord wordt in het maatschappelijke veld in belangrijke domeinen waarin menselijk gedrag centraal staat zoals milieu, energie, mobiliteit en gezondheid, maar ook in het openbaar bestuur als het gaat om het sturen en beïnvloeden van beslissingen van burgers met betrekking tot zaken als de collectieve uitgaven voor de zorg, veiligheid van de openbare ruimte en geldleningen die mensen aangaan, zoals beschreven in het recentelijk verschenen rapport van de Wetenschappelijke Raad voor het Regeringsbeleid getiteld "Met kennis van gedrag beleid maken" (Wetenschappelijke Raad voor het Regeringsbeleid, 2014).

\section{Intervention Mapping}

Bovenstaande aanhorende hoop ik dat u zult begrijpen dat effectieve gedragsverandering geen sinecure is. Effectieve gedragsverandering is zeer moeilijk te realiseren. Per definitie hebben we te maken met complex gedrag ( Peters, 2014; Kok, 2014; Peters, de Bruin, \& Crutzen, 2013). Heel simpel, als gedragsverandering gemakkelijk zou zijn dan zou het al gerealiseerd zijn. Hulp daarbij is dan ook meer dan gewenst. Gelukkig is die hulp er in de vorm van een systematiek, een protocol, dat programmaontwikkelaars concrete richtlijnen geeft voor het toepassen van theorie en onderzoeksresultaten bij het ontwikkelen van gedragsveranderingsprogramma's, Intervention Mapping genaamd (Bartholomew et al., 2011). Het boek dat dit protocol beschrijft, verscheen in 2001 voor het eerst, en is inmiddels in haar $3^{e}$ editie. De vierde editie verschijnt in 2016 en het is voor mij een eer om daaraan als co-auteur te mogen meewerken. 
De bakermat van Intervention Mapping ligt hier in Maastricht in een samenwerkingsverband tussen mijn promotor en mentor Gerjo Kok en zijn Amerikaanse collega's aan de Universiteit van Texas Guy Parcel, Kay Bartholomew en Nell Gottlieb. In de afgelopen 20 jaar, dit jaar hebben we de zoe Summerschool Intervention Mapping verzorgd, zijn tal van mensen in Intervention Mapping getraind, wat terug te zien in het brede gebruik ervan in verschillende domeinen van gedrag (Brijs, Ruiter, \& Brijs, 2009; Kok, Lo, Peters, \& Ruiter, 2011; Kok et al., 2004; Kok, van Essen, et al., 2011; Ruiter et al., 2012). Intervention Mapping heeft inmiddels zijn eigen weg gevonden in het veld van gedragsverandering, en dat tekent het succes van Intervention Mapping.

Intervention Mapping beschrijft de ontwikkeling van gedragsinterventies in zes fasen of stappen. De eerste stap van de probleemanalyse heb ik al besproken. Stap 2 betreft het stellen van specifieke veranderdoelen, op het niveau van de gezondheidsuitkomst (bijvoorbeeld, minder griepinfecties onder personeel in zorg- en ziekenhuisinstellingen), het gedrag (verpleegkundigen laten zich ieder jaar vaccineren tegen de griep) en de gedragsdeterminanten (verpleegkundigen erkennen het belang van de griepvaccinatie en zien deelname hieraan als een vorm van goede patiëntenzorg en niet als een poging van het management het recht op ziekteverlof in te perken). Dit wordt gevolgd door stap 3 waarin methodieken van verandering worden geïdentificeerd, die vervolgens vertaald worden naar praktische toepassingen in overeenstemming met de condities waaronder een methodiek werkzaam is en rekening houdend met kenmerken van de doelgroep en interventiecontext (een rolmodelverhaal waarmee de doelgroep zich kan identificeren en dat als geloofwaardig en relevant wordt beschouwd). Vervolgens wordt een planning opgesteld voor het ontwerpen, produceren en uittesten van de verschillende componenten van het interventieprogramma (stap 4), en een plan voor de implementatie (stap 5) en evaluatie (stap 6) van het programma.

Intervention Mapping wordt hier gepresenteerd als een sequentieel proces, dat is het allerminst. Het proces is iteratief, stappen vooruit worden afgewisseld met stappen achteruit. Het proces wordt geleid door het stellen van taken aan programma-ontwikkelaars. Die taken moeten systematisch worden uitgevoerd waarbij geldt dat de meeste kans op succes verwacht kan worden als theoretische en empirische onderbouwing centraal staat (Bartholomew et al., 2011; Gerjo Kok et al., 2004). Dit is een complex proces waarbij theoretische kennis van gedrag 
en gedragsverandering essentieel is. Gedragswetenschappers moeten dus onderdeel zijn van elk team van programma-ontwikkelaars, maar zijn dat vaak niet (Gerjo Kok, 2014; Peters, de Bruin, et al., 2013). Helaas worden gedragsveranderingsexperts er echter pas bijgehaald op het moment dat allerlei eenvoudigere gedragsinterventies hebben gefaald en de gewenste gedragsverandering zeer moeilijk blijkt te realiseren. De aanname dat mensen zich simpelweg wel redden, met hier en daar een duwtje in de juiste richting, zoals de overheid dat nastreeft in haar beleid van terugtrekkende overheid, en van meer nadruk leggen op de eigen verantwoordelijkheid en keuzevrijheid van burgers, kon dan ook wel eens betekenen dat diezelfde overheid in de nabije toekomst van een koude kermis thuiskomt en beseft dat meer sturing gewenst is.

Intervention Mapping neemt binnen onze onderzoeksgroep Toegepaste Sociale Psychologie een centrale plaats in, niet alleen in ons onderzoek, maar ook in ons onderwijs. Het is een expertise waarmee we ons onderscheiden van anderen en waaraan veel behoefte bestaat in het veld. Het is dus belangrijk onze studenten deze expertise mee te geven. We doen dit met veel enthousiasme binnen onze master Health and Social Psychology en trekken regelmatig het land en de wijde wereld in voor het geven van cursussen Intervention Mapping waarin we met professionals uit het veld het protocol in 5 dagen aan de hand van praktische casussen doorwerken. Een mooie vorm van uitdragen van kennis die we moeten handhaven en waar mogelijk uitbouwen.

\section{Overzicht}

Het graven naar verklaringen van gedrag en het vinden van oplossingen is de essentie van mijn leerstoel Toegepaste Psychologie, waarover ik het in de rest van deze rede wil hebben. Centraal in de titel van mijn leerstoel staat de term Toegepaste Psychologie. Ik zal dan ook beginnen met een definitie van het vakgebied Toegepaste Psychologie zoals wij dat hier in Maastricht bedrijven. Vervolgens zal ik een korte schets geven van de maatschappelijke problematiek waarop wij een antwoord trachten te vinden door toepassing van psychologische kennis over gedragsverandering. Ik zal echter al snel concluderen dat we een soort grens van effectiviteit hebben bereikt en dat we andere wegen moeten bewandelen om die grens te doorbreken, ofwel we zullen dieper moeten graven om effectievere toepassing te realiseren. Hoe ik denk dat we die 
weg vervolgens zouden moeten bewandelen vormt de rest van mijn betoog waarin ik mijn leeropdracht nader toelicht, in het bijzonder hoe ik denk dat het vakgebied van de Cognitieve Neurowetenschappen kan helpen bij het doorbreken van die grens van effectiviteit.

\section{Toegepaste Psychologie}

Tussen de regels door heb ik $u$ al een beeld geschetst van de werkwijze van de Toegepaste Psychologie, of concreter de Toegepaste Sociale Psychologie. Immers de sociale psychologie is het wetenschapsveld waarin ik vooral opereer. Binnen de toegepaste sociale psychologie kunnen twee benaderingen worden onderscheiden: theorie-gestuurde en probleem-gestuurde toegepaste sociale psychologie (Kok, Schaalma, De Vries, Parcel, \& Paulussen, 1996; Ruiter et al., 2012). Theoriegestuurde toegepaste sociale psychologie verwijst naar het toetsen van een theorie in een toegepaste context, met als voornaamste doel inzicht te krijgen in de (externe) validiteit van de theorie, ofwel heeft de theorie ook een praktische waarde of beschrijft de theorie een proces of fenomeen dat alleen terug te vinden is in het laboratorium en weinig relevant is voor de praktijk. Niet een oplossing aandragen is het doel, maar het testen van een theorie.

De term probleem-gestuurde toegepaste sociale psychologie verwijst daarentegen naar wetenschappelijk onderzoek dat erop gericht is een maatschappelijk probleem te veranderen of te reduceren. Hoewel gebruik wordt gemaakt van theorie, is de probleem-gestuurde toegepaste sociale psychologie primair gericht op probleemoplossing en wordt succes geformuleerd in termen van reductie van het probleem. Eventuele bijdrage aan theorievorming is mooi meegenomen (een prettige bijvangst) maar geen noodzaak. Als ik het heb over toegepaste psychologie dan doel ik op de probleemgerichte benadering waarin gestart wordt met een uitgebreide probleemanalyse en waarin getracht wordt vanuit een breed en multi-theoretisch kader een oplossing voor de problematiek aan te dragen.

In allerleionderzoeksprojecten, vooral in het kadervan promotieonderzoek, hanteren wij deze probleemgerichte benadering. Heel systematisch kijken wij naar het waarom van gedrag en hoe we dat gedrag vervolgens succesvol kunnen beïnvloeden. $U$ zult waarschijnlijk denken: "Dat is niets 
nieuws, dat zou een ieder moeten doen, waarmee onderscheiden jullie je van anderen?" De expertise van Intervention Mapping zit hem vooral in het constant terug grijpen op theorie en empirisch onderzoek bij het doorlopen van het gedragsveranderingsproces. Daarbij werken we vanuit een breed theoretisch kader, vanuit het besef dat een enkele theorie de wereld niet kan verklaren. Immers, een theorie is een reductie van de werkelijkheid tot de essentiële elementen. Dat is geen tekortkoming maar simpelweg een definitie (Kok \& Ruiter, 2014). De unieke vaardigheid van een toegepast psycholoog is dat hij of zij bij iedere vraag de juiste theorie weet te vinden om een antwoord te formuleren. En als die theorie niet voorhanden is, gaat hij zelf op onderzoek uit om antwoorden te formuleren.

\section{Is gedragsverandering effectief?}

De vraag die we ons kunnen en voortdurend ook moeten stellen, en die ook centraal staat in mijn leerstoel, is of we goed bezig zijn. Zijn de interventies van gedragsverandering zoals wij die voor ogen hebben effectief? Het antwoord van mij op deze vraag is: ja, mits de ontwikkeling van de gedragsinterventie goed gebeurt. Met goede interventies bedoel ik gedragsveranderingsprogramma's die systematisch en planmatig tot stand komen, vanuit een breed theoretisch kader en met een gedegen empirische onderbouwing van doelgroep, gedrag en in te zetten methodieken van verandering. Een voorbeeld hiervan is het programma Lang Leve de Liefde, een schoolprogramma over seksualiteit en het bevorderen van veilig seksueel gedrag voor het middelbaar onderwijs dat in de jaren 90 is ontwikkeld door Herman Schaalma in samenwerking met Soa-Aids Nederland, in het bijzonder Jos Poelman en Suzanne Meijer, en de GGD Rotterdam. Dit programma is door de genoemde instituten in nauwe samenwerking met mijn collega's, Intervention Mapping experts, Fraukje Mevissen en Gerjo Kok uitgebreid tot een breed omvattend programma voor verschillende niveaus binnen het middelbaar onderwijs. Binnen dit lesprogramma is de versie voor de onderbouw onlangs beoordeeld met het hoogste keurmerk van kwaliteit door het Centrum Gezond Leven, dat gedragsveranderingsprogramma's beoordeelt op basis van theoretische onderbouwing en effectiviteit. Lang Leve de Liefde is daarmee het enige seksuele voorlichtingsprogramma in NL dat als effectief is beoordeeld (Soa Aids Nederland, 2014). 
Bewijs voor de effectiviteit van gedragsverandering is ook te vinden in meta-analyses van gedragsinterventies die laten zien dat interventies met een gedegen theoretische onderbouwing effectiever zijn dan interventies waarvan het achterliggende denkwerk niet systematisch heeft plaatsgevonden of zelfs ontbreekt (Albarracín et al., 2005; Bruin et al., 2014; Godin, Gagnon, Alary, Levy, \& Otis, 2007; van Achterberg et al., 2011). Bijvoorbeeld, in een statistische analyse van meer dan 300 interventies om condoomgebruik te bevorderen laat Dolores Albarracín zien dat actieve interventies effectiever zijn in het bevorderen van condoomgebruik dan passieve interventies en het ontvangen van geen interventie. En, belangrijk, dat passieve interventies niet effectiever zijn dan het ontvangen van geen interventie (Albarracín et al., 2005). Passieve interventies zijn interventies die tot doel hebben mensen te informeren, denk bijvoorbeeld aan de eerder genoemde tv-spotjes, affiches, voorlichtingsfoldertjes en websites die ons moeten overtuigen wat wel of niet verstandig is om te doen. Er is sprake van eenrichtingsverkeer, van zender naar doelgroep, zonder dat de doelgroep daar een actieve rol in heeft. Actieve interventies gebruiken ook passieve strategieën, maar daarnaast wordt de doelgroep actief betrokken bij de interventie. Er is sprake van tweerichtingsverkeer. Interventies worden bijvoorbeeld op individuele behoeftes afgestemd (voorlichting op maat) en er is sprake van training van vaardigheden waarin de doelgroep bepaald gedrag moet oefenen en vervolgens daar feedback op ontvangt. Kortom, actieve interventies zijn over het algemeen omvattender van aard, vergen meer planning en hebben een uitgebreidere inhoudelijke grondslag; en zijn dus effectiever. Andersom geredeneerd, complexe gedragsverandering los je niet met simpele informatieboodschappen zoals een brochure, poster of TV spotje op.

Tot slot is er bewijsvoering voor de effectiviteit van gedragsveranderingsprogramma's in de landelijke cijfers over de belangrijkste leefstijlfactoren en determinanten van gezondheid. Zo laat de onlangs verschenen nieuwste versie van het belanghebbende rapport Volksgezondheid Toekomst Verkenning (VTV) zien dat er wat betreft de belangrijkste leefstijlfactoren, namelijk roken, alcohol, beweging en voeding, goed nieuws is te melden (RIVM, 2014). De laatste jaren is zowel het percentage rokers als het percentage mensen dat onvoldoende beweegt gedaald. Ook laat het rapport zien dat de vermijdbare sterfte, dat is de sterfte aan ziektes, die binnen de huidige stand van de zorg en de wetenschap, 
behandeld of voorkomen kunnen worden, is verminderd van bijna 110 doden per 100.000 inwoners in 2001 naar iets minder dan 80 in 2012. Het rapport geeft als redenen hiervoor de verbeterde zorgtechnieken en preventie. Daarbij dient wel opgemerkt te worden dat collectieve preventiemaatregelen zoals de bevolkingsonderzoeken borstkanker en baarmoederhalskanker, het Rijksvaccinatieprogramma voor kinderen en de behandeling van hoge bloeddruk in de huisartspraktijk de meeste bijdrage leveren aan het reduceren van voorkombare sterfte en ziektegevallen. Het effect van individuele preventie, gericht op mensen met een verhoogd risico, ligt veel lager, ondanks de vele honderden leefstijlinterventies die beschikbaar zijn, maar waarvan er dus slechts enkelen theoretisch goed onderbouwd en bewezen effectief zijn.

Dezelfde cijfers laten ons ook zien dat we kritisch moeten blijven. De leefstijl van veel Nederlanders kan een stuk gezonder. Dit blijkt als we de vier belangrijkste leefstijlfactoren (roken, alcohol, beweging en voeding) op een rij zetten: tien procent drinkt te veel, een kwart rookt, een derde beweegt te weinig en zowat iedereen eet te weinig groente en fruit. Weliswaar behoort Nederland tot de meest verkeersveilige landen van de wereld. Door maatregelen op het gebied van infrastructuur, wetgeving, handhaving, voertuigveiligheid, maar ook voorlichting (denk aan de verkeerseducatie in het basisonderwijs), is het aantal dodelijke slachtoffers weliswaar gedaald van meer dan 3.000 begin jaren zeventig naar 650 in 2012. Als we echter kijken naar de ongevalsstatistieken voor de verschillende leeftijdsgroepen dan zien we dat vooral jongeren en ouderen een sterk verhoogd risico lopen op een ongeval met gezondheidsschade of zelfs de dood (Centraal Bureau voor de Statistiek, 2014). En weliswaar gebruiken steeds meer jongeren een condoom de eerste keer met een nieuwe partner, maar nog steeds doet 30\% van de jongeren dat niet, ondanks de uitgebreide voorlichting die zij hierover krijgen en de kennis die ze hebben van seksueel overdraagbare aandoeningen waaronder HIV/aids (RIVM, 2014b). Bovendien zijn er nieuwe ontwikkelingen, zoals de exponentiele toename in het aantal jongeren dat wordt opgenomen met alcoholvergiftiging in de weekenden en de dodelijke ongelukken met party-drugs, waarop we niet goed vat op lijken te hebben maar die wel een inspanning van ons noodzakelijk maken in de vorm van innovatieve gedragsveranderingsprogramma's, omdat de huidige programma's blijkbaar niet voldoen en wet- en regelgeving onvoldoende een optie zijn (RIVM, 2014). 
Kortom, er lijkt een soort grens van effectiviteit te zijn bereikt voor gedragsverandering door middel van educatie en voorlichting. We doen veel, er zijn talloze leefstijlinterventies beschikbaar, er is veel bereikt, maar er lijkt een soort van status quo bereikt. Door collega Josh Tybur van de VU in Amsterdam wordt deze grens van effectiviteit treffend beschreven als een 'glazen plafond' van effectiviteit: een maximumgrens van effectiviteit van gedragsinterventies waar we wel doorheen willen breken, we zien waar we naartoe moeten, maar we kunnen het niet (Tybur, Bryan, \& Caldwell Hooper, 2012).

\section{Dieper graven voor effectievere toepassing}

Mijn leerstoel heeft als primaire taak oplossingen te bedenken die de effectiviteit van gedragsveranderingsprogramma's kunnen vergroten. Dat is ookdetaakstellingvanonzeonderzoeksgroepToegepasteSocialePsychologie waar ik met veel plezier werk. Als groep proberen we op verschillende manieren de effectiviteit van gedragsveranderingsprogramma's te verbeteren. Natuurlijk door sterk te hameren op een correcte toepassing van gedragsveranderingstheorie, zoals hierboven beschreven. Maar ook door het niveau van analyse en interventie te verleggen. Bijvoorbeeld, evolutionair en sociaal psycholoog Karlijn Massar en promovendus Stefan Gruijters kijken samen met Josh Tybur van de VU naar de rol die basale evolutionaire motieven gerelateerd aan succesvolle voortplanting en vermijding van ziekten een rol kunnen spelen bij het bevorderen van gezondheidsgedrag. We verleggen onze aandacht naar specifieke doelgroepen en specifieke interventie-omgevingen. Bijvoorbeeld in het onderzoek van Dilana Schaafsma naar de grote hiaten die er zijn op het gebied van seksualiteit en educatie voor mensen met verstandelijke beperkingen die in instellingen verblijven. Met Fred Zijlstra, Robert van Doorn en Suzanne van Gils van de sectie Arbeid en Organisatie Psychologie kijken we naar mogelijkheden voor de ontwikkeling en implementatie van gedragsveranderingsprogramma's op de werkvloer om zo gezonde en vooral duurzame arbeid te creëren. Allemaal interessant toegepast onderzoek waarin we breder kijken dan we gewend zijn om zo verrijking te vinden voor effectievere toepassing van gedragsverandering. Onderzoek waarvan we in de toekomst hopelijk gaan horen, maar waarvoor nu helaas de tijd ontbreekt om hier dieper op in te gaan. In de rest van mijn rede wil ik namelijk aandacht besteden aan de ondertitel van mijn leerstoel; waarom en hoe ik denk dat de cognitieve neurowetenschappen een bijdrage kunnen leveren aan de verbetering van gedragsveranderingsprogramma's. 


\section{Rol van de cognitieve neurowetenschappen}

Het doel van de Cognitieve Neurowetenschappen is te beschrijven hoe belangrijke psychologische en cognitieve processen zoals geheugen, aandacht en bewustzijn, emotie en taal zich binnen de hersenen afspelen. Naast de vraag waar in de hersenen zich deze processen afspelen, tracht de cognitieve neurowetenschapper inzicht te krijgen in de specifieke werking (het 'hoe') van deze processen in het brein. De grote kracht van de Cognitieve Neurowetenschap ligt in haar onderzoeksinstrumentarium. $\mathrm{Er}$ is een breed scala aan onderzoekstechnieken voorhanden die het mogelijk maakt de processen functies waarin we geïnteresseerd zijn te meten terwijl het brein in actie is. Waar we bij vragenlijst- en gedragsonderzoek altijd genoodzaakt zijn tot indirecte, afgeleide maten van de psychologische processen die het gedrag aansturen, kunnen we met technieken uit de cognitieve neurowetenschappen heel direct kijken naar die processen terwijl ze optreden en zonder dat we de schedel hoeven te lichten.

Een voorbeeld van een dergelijke techniek is EEG-onderzoek waarbij we door middel van elektrodes die op de schedel worden geplakt de elektrische activiteit van de hersenen kunnen meten. Als we dit elektroencefalogram bekijken dan kunnen we met een geoefend oog en gedetailleerde analyses specifieke conclusies trekken over de toestand van het brein; of het brein bijvoorbeeld heel actief is en geconcentreerde arbeid levert of dat het juist in een rusttoestand verkeert). Maar wat ook opvalt is, dat er sprake is van een zeer complex beeld van activitatiepatronen en dat het moeilijk bepalen is of het brein op bijvoorbeeld een angstaanjagend plaatje over de negatieve gevolgen van roken anders reageert dan op een neutraal plaatje over waar hulp te zoeken bij het stoppen met roken. Dit complexe beeld is het gevolg van ruis omdat de hersenen steeds net iets anders op een zelfde stimulus reageren maar ook het gevolg van spieractiviteit bijvoorbeeld bij het knipperen met de ogen. Een simpele techniek om die ruis eruit te halen is door de plaatjes heel vaak aan te bieden en vervolgens de elektrische hersenactiviteit in reactie op die plaatjes te middelen. Dan ontstaat er een zeer stabiel patroon van hersenactiviteit, genaamd een event-related brain potential (ERP); in mooi Nederlands: gebeurtenisgerelateerde hersenpotentialen. ledere piek in een dergelijk plaatje is een ERP component en omdat ERP onderzoek een relatief oude onderzoekstechniek is en er vooral sinds de intrede van de personal computer in het begin van de jaren 80 veel onderzoek mee is gedaan, weten we inmiddels heel goed wat componenten als de N100, N200, 
P300, N400, P6oo betekenen in termen van psychologische processen als waarneming, aandacht, taalbegrip en geheugen.

Mocht dit alles $u$ als abracadabra in de oren klinken, ik kan $u$ gerust stellen, dat deed het voor mij in eerste instantie ook. Ik ben immers geen psycholoog, maar ook geen neurowetenschapper. Maar, het goede nieuws is, het doen van EEG en ERP onderzoek is te leren, hoewel niet zonder deskundige hulp. Gelukkig had ik die hulp, in eerste instantie van onze decaan Bernadette Jansma, die mij wegwijs maakte in EEG onderzoek en later van Loes Kessels toen student met zowel een opleiding in de onderwijspsychologie als cognitieve neurowetenschappen, later mijn promovendus en nu universitair docent in onze groep. Gedrieën hebben we binnen het veld van de gezondheidspsychologie innovatieve studies uitgevoerd naar processen van aandacht bij blootstelling aan gezondheidsinformatie (Falk, 2010). In het bijzonder hebben we gekeken naar de effecten van angstaanjagende voorlichting op defensieve reacties. Deze gedragsveranderingstechniek van schrik aanjagen voor de negatieve gevolgen van ongezond gedrag wordt veel gebruikt, maar de effectiviteit daarvan betwisten we al jaren op basis van theorie en het empirische onderzoek van onszelf en dat van anderen (Peters, Ruiter, \& Kok, 2013; Ruiter, Kessels, Peters, \& Kok, 2014; Ruiter, Abraham, \& Kok, 2001). De theorie is duidelijk: als je mensen wilt wijzen op de ernstige negatieve gevolgen van ongezond gedrag wees er dan zeker van dat zij beschikken over een alternatief voor hun ongezonde gedrag waarvan ze overtuigd zijn dat het helpt in het voorkomen van die negatieve gevolgen en, heel belangrijk, dat zij het vertrouwen hebben dat zij dat alternatieve gedrag (stoppen met roken, veiligheidsgordel dragen op de achterbank van een auto) ook kunnen uitvoeren. Maak je iemand bang voor iets dat hij graag doet, maar is gedragsverandering geen optie dan blijft er voor bijvoorbeeld een roker nog maar één effectief middel over om met zichzelf in het reine te blijven: ontkenning van de risico's en vermijding van de informatie. Met behulp van ERP onderzoek hebben we aangetoond dat proefpersonen voor wie de bedreigende informatie relevant is inderdaad hun aandacht afwenden van dit soort angstaanjagende informatie (Kessels, Ruiter, Brug, \& Jansma, 2011; Kessels, Ruiter, \& Jansma, 2010; Kessels, Ruiter, Wouters, \& Jansma, 2014; Kessels \& Ruiter, 2012)especially when the information challenges selfrelevant goals. The authors investigated whether reduced acceptance of self-relevant health risk information is already visible in early attention processes, that is, attention disengagement processes. DESIGN: In a 
randomized, controlled trial with 29 smoking and nonsmoking students, a variant of Posner's cueing task was used in combination with the hightemporal resolution method of event-related brain potentials (ERPs.

De vraag die dan natuurlijk rijst is hoe risico-informatie wél op een effectieve manier te communiceren? In verschillende projecten proberen we een antwoord te vinden op deze vraag. In een onderzoekslijn van Fraukje Mevissen en Ree Meertens kijken we naar de effecten van verschillende wijzen waarop risico-informatie kan worden gepresenteerd (Mevissen, Meertens, Ruiter, \& Schaalma, 2010; Mevissen, Ruiter, Meertens, \& Schaalma, 2010). Moeten we risico's bijvoorbeeld in kansen presenteren of is het beter dat meer verhalenderwijs te doen, zodat mensen zich gemakkelijk een voorstelling kunnen maken van het risico. In een meer directe voortzetting van het eerdere ERP onderzoek kijken we binnen het promotieproject van Esther Silbernagel in samenwerking met professor Peter Harris van de University of Sussex in Groot Brittannië of het bevestigen van het positieve zelfbeeld van mensen ertoe kan leiden dat zij de aandacht niet afwenden van persoonlijk relevante doch bedreigende informatie maar juist de aandacht erop richten en de informatie op zichzelf richten in plaats van ontkennen.

Binnen mijn leerstoel zal ERP onderzoek een belangrijke plaats blijven innemen. De hoge nauwkeurigheid waarmee gemeten kan worden als het gaat om wanneer welke psychologische processen optreden (temporele resolutie) en de heldere inzichten die we hiermee verkrijgen in het begrijpen van hoe mensen omgaan met gezondheidsinformatie, niet alleen in termen van aandacht voor de informatie maar ook met betrekking tot meer diepere processen van informatieverwerking, zoals tekstverwerking, maakt de techniek een genot om mee te werken.

ERP onderzoek maakt het mogelijk heel nauwkeurig te bepalen op welk moment een psychologisch proces, zoals bijvoorbeeld aandacht voor informatie, optreedt; tot op de milliseconde nauwkeurig wordt de activiteit van vurende neuronen in ons brein opgepikt. Maar ERP is veel minder goed in staat te bepalen waar in het brein die processen zich afspelen (spatiële resolutie). Een techniek die veel beter in staat is om te bepalen waar processen zich afspelen is functional magnetic resonance imaging, ofwel functionele MRI of fMRI. Met deze techniek, waarbij mensen liggend in een scanner worden geplaatst, wordt niet de elektrische activiteit van de hersenen gemeten, maar wordt 
hersenactiviteit gemeten op basis van de sterkte van de doorbloeding van de hersengebieden waarin we geïnteresseerd zijn op momenten dat die gebieden wel versus niet actief zijn (bijvoorbeeld activatie in de motorische gebieden bij het bewegen van een arm of been, of in de visuele gebieden bij het kijken naar patronen.

In vergelijking tot ERP, is $\mathrm{fMRI}$ een relatief nieuwe onderzoekstechniek. Sinds haar introductie in het begin van de jaren 90 van de vorige eeuw heeft het onderzoek met fMRI een enorme vlucht genomen. De exponentiele, feitelijk niet meer bij te houden groei van publicaties heeft ertoe geleid dat niet alleen kennis van de anatomie van het brein enorm is toegenomen, maar vooral ook zijn we veel meer te weten gekomen over welke hersengebieden zich met welke psychologische processen bezighouden en hoe de gebieden daarover in netwerken met elkaar communiceren. Deze vlucht in kennis van het brein creëert een situatie waarin de cognitieve neurowetenschappen meer dan ooit kunnen bijdragen aan het begrijpen van gedrag, maar ook belangrijke inzichten kunnen leveren voor innovatieve gedragsinterventies om zo effectiever te kunnen opereren.

\section{Brein als uitkomst}

Omdat we nu zoveel weten van het brein - let wel, het brein is zo complex, we weten waarschijnlijk nog steeds heel veel niet - heeft het meer dan ooit zin om mensen in de scanner te leggen en te kijken welke psychologische processen optreden als we mensen blootstellen aan gedragsveranderingsinterventies of in bepaalde situaties te brengen waarbij we geïnteresseerd zijn in hun gedrag, meer bepaald in hun gedragskeuzes. Net zoals bij eerder genoemd ERP onderzoek, nemen we de hersenactiviteit als uitkomstmaat en leren we over de psychologie van gedrag. We doen dit bijvoorbeeld in een project van promovendus Martin Sona naar de stigmatisering en sociale uitsluiting van mensen met HIV, het virus dat aids veroorzaakt. Een project dat ik begeleid samen met Vincent van de Ven van de capaciteitsgroep Cognitieve Neurowetenschappen, stigma-expert Arjan Bos, die voorheen bij ons werkzaam was maar nu aan de Open Universiteit in Heerlen zetelt en de voormalige postdoc op dit project Jane Banfield. We zijn geïnteresseerd in hoe ons brein omgaat met een situatie waarin we geconfronteerd worden met een persoon met HIV, het virus dat aids veroorzaakt. De kennis die we hebben is beperkt tot vragenlijstonderzoek naar attitudes en intenties en gedragsobservaties, waarbij we kijken naar de afstand 
die we bewaren van mensen met HIV. Binnen het fMRI project hopen we meer te leren over welke psychologische processen een rol spelen bij het wel of niet uitsluiten van mensen met HIV om zo interventies die tot doel hebben stigmatisering van mensen met HIV tegen te gaan beter te kunnen inrichten.

In een eerste studie spelen mensen een balspel, Cyberball genaamd, met twee andere personen. In origineel onderzoek van Naomi Eisenberger en collega's (Eisenberger, Lieberman, \& Williams, 2003) speelde de proefpersoon mee maar werd hij op een gegeven moment uitgesloten van deelname omdat de twee andere personen de bal alleen nog maar naar elkaar gooiden en niet naar de proefpersoon. Sociale exclusie is een uitgebreid bestudeerd fenomeen in de sociale psychologie, maar dit fMRI onderzoek is baanbrekend geweest in het begrijpen van de effecten van sociale exclusie. Op het moment dat de proefpersoon ervoer dat hij werd buitengesloten werd namelijk activiteit gevonden in dezelfde hersengebieden als wanneer een persoon fysieke pijn voelt.

Buitensluiting door anderen gaat dus gepaard met de ervaring van fysieke pijn. In ons project zijn we vooral geïnteresseerd in hoeverre gevoelens van empathie en medelijden, en daaraan gerelateerde hersengebieden en -netwerken een rol spelen als proefpersonen kijken naar een situatie waarin iemand waarvan bekend is dat hij HIV heeft wordt buitengesloten door anderen of wanneer de proefpersoon hieraan zelf actief deelneemt.

\section{Brein als voorspeller}

Meer van dit type onderzoek waarin hersenactiviteit ons iets leert over de psychologische processen die een rol spelen, staat gepland. Mooi onderzoek omdat het de noodzakelijke verdieping geeft van ons begrip van gedrag. Graag wil ik binnen mijn leerstoel dit onderzoek echter uitbreiden naar studies waarin we kijken naar de mate waarin de neurale metingen die we doen toekomstig gedrag ook kunnen voorspellen. Metingen aan het brein fungeren dan niet alleen als uitkomst van psychologische processen, maar tevens als voorspeller van toekomstig gedrag (brein als voorspeller; Berkman \& Falk, 2013). Door de Amerikaanse onderzoeker Emily Falk wordt dit type onderzoek al bedreven. In één van haar studies mat zij met fMRI de hersenactiviteit van rokers terwijl zij werden blootgesteld aan drie versies van een TV-spotje waarin rokers worden aangemoedigd een hulplijn over 
stoppen met roken te bellen (Falk, Berkman, \& Lieberman, 2012). In het bijzonder was zij geïnteresseerd in de hersenactiviteit in gebieden van de mediale prefrontale cortex omdat eerder onderzoek had laten zien dat activiteit in deze gebieden geassocieerd is met gedragsverandering. Nadat de proefpersonen de verschillende versies van de spotjes hadden gezien vroeg zij proefpersonen tevens door middel van een vragenlijst aan te geven welk versie van het spotje zij verwachten dat het meest effectief zal zijn.

De resultaten lieten zien dat de versie van het TV-spotje die de meeste activiteit in de mediale prefrontale cortex genereerde inderdaad het meest effectief bleek, want die versie genereerde de meeste bellers. Opvallend, vragen naar welk versie de proefpersonen het meest effectief vonden bleek daarentegen geen voorspeller te zijn van de daadwerkelijke effectiviteit van de verschillende versies. Die voorspellingen waren in hoge mate onjuist. Overigens, misschien een niet zo verbazende bevinding, achteraf bezien dan, omdat vragen naar effectiviteit ook in ons eigen onderzoek het vaak aflegt tegen het daadwerkelijk meten van effectiviteit (Ten Hoor et al., 2012)but frequently have no effect or even a counterproductive effect on behavior change. This paradox (i.e. wide application despite low effectiveness.

Blijkbaar zijn we in staat effectiviteit van gedragsinterventies te voorspellen op basis van de hersenactiviteit die we meten en fungeert een dergelijke neurale pretest van interventies beter dan onze traditionele pilot tests waarin we vragen wat mensen denken dat het effect zal zijn, zoals we bijvoorbeeld zien in de wetenschappelijke ondersteuning die wordt aangedragen voor het introduceren van enge plaatjes op sigarettenpakjes, zoals we die volgend jaar ook in Nederland te zien krijgen.

Samen met Loes Kessels en recentelijk ook Eva Janssen van de capaciteitsgroep Gezondheidsbevordering ben ik bezig met het ontwikkelen van onderzoeksideeën om dit principe van brein als voorspeller breder toe te passen als het gaat om de effectiviteit van risicocommunicatie. Tevens ligt in dit kader een combinatie van fMRI onderzoek en gedragsobservatie binnen dezelfde proefpersoon erg voor de hand, bijvoorbeeld in het onderzoek naar stigmatisering van mensen met HIV. Expertise hiervoor hebben we al in huis en met een volwaardig Virtual Reality lab maar ook een rijsimulator beschikken we ook over de 
technische faciliteiten om gedrag te observeren in levensechte maar gecontroleerde omstandigheden. Onderzoeksfaciliteiten waarvan we gebruik maken in onderzoek van promovendus Henna Toppenberg, wederom naar stigmatisering van mensen met HIV waarbij we in een virtuele proefpersonen vragen op een persoon met HIV af te stappen (Toppenberg, Bos, Ruiter, Wigboldus, \& Pryor, in druk), en in samenwerking met de Universiteit Hasselt, hier vlak over de grens in België, in het kader van onderzoek naar risicogedrag van jongeren in het verkeer, waar ik tot slot van mijn rede het kort met $u$ over wil hebben (Ross, Jongen, Brijs, et al., 2014; Ross, Jongen, Wang, et al., 2014).

\section{Brein als richting gever}

Zoals ik $u$ al eerder meldde vormen jongeren een belangrijke risicogroep in het verkeer op het moment dat zij zich zelfstandig in het verkeer gaan begeven, op de fiets, op de scooter of in de auto. In Hasselt ben ik betrokken bij onderzoek dat misschien wel het meest tot voorbeeld strekt van de waardevolle bijdrage die de cognitieve neurowetenschappen kan leveren aan de verbetering van de effectiviteit van gedragsinterventies. Dit onderzoek is gebaseerd op recente inzichten over de ontwikkeling van de hersenen in de periode van geboorte tot volwassenheid, in het bijzonder op het baanbrekende werk van de Noord Amerikaanse onderzoekers Jay Giedd en Tomas Paus rond de millenniumwisseling (Giedd et al., 1999; Paus, 2005)both global and local. There is less agreement on the meaning of asynchronous age-related decreases in the volume of grey matter in different cortical regions; these might equally represent loss ( "pruning।". Met behulp van longitudinale fMRI studies waarin deelnemers op meerdere momenten tijdens hun jeugd in de scanner werden gelegd, lieten zij en vervolgens talloze anderen zien dat de ontwikkeling van onze hersenen niet voltooid is ergens in de kinderjaren of pubertijd, maar dat de hersenontwikkeling doorgaat tot ver in onze twintiger jaren. Wat we zien is een brein dat zich steeds efficiënter organiseert door overbodige grijze materie op te ruimen - grijze materie is de stof waarin de zenuwcellen zich bevinden en de informatieverwerking plaatsvindt - en de communicatie tussen zenuwcellen te verbeteren door een toename van witte materie.

Van belang voor ons onderzoek naar risicogedrag van jongeren is dat er een tweespalt ontstaat in de ontwikkeling van twee belangrijke onderdelen van ons brein. Van belang voor ons onderzoek naar risicogedrag van jongeren is dat er een tweespalt ontstaat in de 
ontwikkeling van twee belangrijke onderdelen van ons brein. Aan de ene kant een relatief heftige en snelle ontwikkeling tijdens de puberteit van dat deel van de hersenen, het limbisch systeem, dat zeer gevoelig is voor allerlei negatieve en positieve prikkels in de omgeving van de persoon, bijvoorbeeld de mate waarin belangrijke anderen, in het bijzonder leeftijdsgenoten, gedrag goed- of afkeuren. En aan de andere kant een langzame, meer geleidelijke ontwikkeling van hersenstructuren in frontale en pariëtale hersengebieden die essentieel zijn bij het omgaan met korte termijn beloningen in het licht van lange termijn doelen. Het gedeelte van het brein dat allerlei belangrijke cognitieve functies verzorgt voor een succesvol dagelijks functioneren, zoals nee kunnen zeggen tegen verleidingen op momenten dat dat verstandig is, het vooruit kunnen plannen van gedrag, een voorstelling kunnen maken van de gevolgen van gedrag, maar ook het kunnen inleven in de gevoelens van anderen; allemaal functies die je nodig hebt in het normale dagelijkse functioneren en die worden aangeduid met de term basale cognitieve functies of executieve functies.

Wat we dus zien is een adolescenten brein dat zeer gevoelig is voor allerlei beloningen en gevoelens in de sociale omgeving, maar nog niet in staat is om daar effectief mee om te gaan; kortom, we hebben bij jongeren te maken met een psychosociaal onvolwassen brein. Het is niet zozeer dat jongeren de risico's niet kennen, wat de aanname is van allerlei gedragsinterventies die tot doel hebben jongeren voor te lichten over de gevaren van het verkeer, maar ze zijn niet in staat op een effectieve manier met die risico's om te gaan(Steinberg, 2007, 2009).

Door collega Reinout Wiers in onderzoek naar de invloed van impulsieve versus meer beredeneerde processen op gedrag beschreven in een metafoor van een paard en zijn berijder, waarin het paard staat voor het sterk reagerende sociaal-emotionele, impulsieve deel van het brein dat alleen succesvol gecontroleerd kan worden als de ruiter - hoe toepasselijk - over voldoende cognitieve vaardigheden beschikt (Hofmann, Friese, \& Wiers, 2008; Wiers, Gladwin, Hofmann, Salemink, \& Ridderinkhof, 2013).

De onvolwassenheid van het adolescentenbrein wordt treffend geillustreerd in twee studies van Steinberg en collega's waarin ze adoloscenten, jong volwassenen en volwassenen lieten rijden in een rijsimulator, ofwel alleen ofwel met een leeftijdsgenoot naast hen. Rijden ze alleen dan doen adolescenten het net zo goed als beide 
groepen volwassenen, maar als je een leeftijdsgenoot naast hen zet dan gaat het mis, ze veroorzaken dan meer ongelukken (Chein, Albert, O'Brien, Uckert, \& Steinberg, 2011; Gardner \& Steinberg, 2005). fMRI resultaten laten zien dat het toegenomen risicogedrag verklaard kan worden door meer activatie van het sociaal-emotionele systeem van het brein dat gevoelig is voor beloningen, in dit geval de simpele aanwezigheid van leeftijdsgenoten waarop indruk moet worden gemaakt (Chein et al., 2011). De jonge ruiter is onvoldoende in staat zijn paard te controleren.

De uitdaging die ik ben aangegaan met mijn collega's in Hasselt Ellen Jongen, Kris Brijs en Tom Brijs van het Instituut Mobiliteit (IMOB), is of we de natuurlijke ontwikkeling van die basale cognitieve functies als werkgeheugen, response inhibitie en gevaardetectie kunnen versnellen door middel van specifieke trainingen. In een eerste fase van onderzoek heeft Veerle Ross, onze oud-studente en thans promovendus in Hasselt, steun gevonden voor de rol van executieve functies als response inhibitie en werkgeheugen bij het verklaren van risicovol rijgedrag (Ross, Jongen, Brijs, et al., 2014; Ross, Jongen, Wang, et al., 2014). Dat is een mooi begin. De vraag is nu of we die functies kunnen versterken met specifieke trainingen en zo het rijgedrag van jongeren in risicovolle situaties kunnen beïnvloeden. Onderzoek dat plaatsvindt in hun up-to-date rijsimulator. In het project van promovenda Weixin Wang in Hasselt hopen we hierop binnenkort antwoord te krijgen.

Bewijs voor de effectiviteit van het trainen van executieve functies op risicogedrag is voorhanden in de literatuur, bijvoorbeeld in het onderzoek van Katrijn Houben binnen onze faculteit en Reinout Wiers, die voorheen in Maastricht werkzaam was maar alweer enige hoogleraar aan de Universiteit van Amsterdam. Zij doen vooral onderzoek naar verslavingsgedrag en benaderen dit vanuit de zojuist beschreven ruiterpaard metafoor, door niet alleen de ruiter te trainen, maar ook middels pogingen het pard te temmen, bijvoorbeeld door positieve associaties die alcoholverslaafden hebben ten aanzien van alcoholische dranken om te zetten naar negatieve associaties. Zo moesten in een klinische studie alcoholverslaafden in meerdere sessies plaatjes met alcoholische dranken van zich af duwen. Het simpelweg wegduwen van plaatjes resulteerde niet alleen in een sterkere associatie van alcohol met vermijding dan met toenadering, maar leidde er ook toe dat deze groep minder teruggreep naar de fles dan een controlegroep tot zelfs 12 maanden na de interventie. Een indrukwekkend effect (Eberl et al., 2013). 
Samen met Katrijn en Reinout proberen we de kennis van het adolescentenbrein en de implicaties voor hoe jongeren met risicovolle situaties omgaan ook toe te passen op het terrein van soa en aids preventie in een project van promovendus Phil Brüll. Een eerste versie van een trainingsprogramma staat bijna klaar om getest te worden. Doel van het programma is veilig seksueel gedrag in risicovolle situaties te bevorderen, enerzijds door jongeren meer weerbaar te maken door het versterken van de executieve functies (ofwel het versterken van de ruiter), anderzijds door negatieve associaties die jongeren hebben over veilig vrijen, zoals "condooms zijn onhandig of vormen een hinderlijke onderbreking", om te zetten in meer positieve associaties (ofwel het temmen van het paard). We doen dit in de vorm van een computerspel in de verwachting dat dit jongeren meer zal motiveren mee te doen aan de interventie en die ook af te maken. Innovatief en daardoor risicovol maar bovenal spannend onderzoek.

\section{Afsluiting}

Ik ben zo langzamerhand aan het einde van mijn rede gekomen. Wat ik in mijn rede heb proberen te doen is $u$ inzicht te geven in mijn wetenschappelijke achtergrond (psychologie met een sterke hang naar toepassing), expertise (gedragsverandering) en ambities (toepassen van nieuwe kennis, in het bijzonder die uit de cognitieve neurowetenschappen, bij het effectiever maken van gedragsinterventies). Ik hoop dat ik daar een beetje in ben geslaagd. Wat ik niet heb kunnen doen is $u$ vertellen over andere zaken die mij bezighouden, waaronder het onderwijs. Ik ben natuurlijk ook vooral docent. Ik doe dat graag maar zie ook uitdagingen waarmee we iets moeten. Ik bemoei me daar graag tegen aan, ook in deze rol zal ik dat blijven doen, op mijn eigen manier.

En dan is er natuurlijk mijn grote hobby, namelijk het onderzoek dat ik doe in Westelijk en Zuidelijk Afrika waarin we Afrikaanse promovendi opleiden tot zelfstandige onderzoekers. Daarbij gaat het om basale gezondheidsproblemen zoals de hoge HIV/aids prevalentie in vooral Zuid-Afrika, het hoge aantal tienerzwangerschappen in Noord Ghana aan de grens met Burkina Faso en het beperkte gebruik van gezondheidsklinieken door zwangere vrouwen als ze moeten bevallen op het platteland van Zambia. Stuk voor stuk problemen van een andere orde. Daar een bijdrage aan kunnen leveren door het opleiden van 
goede gedragswetenschappers geeft een enorme voldoening, niet in de minste plaats door mijn langdurige samenwerking met mijn mentor op dit gebied emeritus hoogleraar Bart van den Borne en in nauwe samenwerking met Priscilla Reddy, onderzoeksdirecteur aan de Human Science Research Council in Kaapstad. Gelukkig vind dit plezierige virus van, noem het maar, 'ontwikkelingswerk' ook zijn weg in de jongere generatie binnen onze onderzoeksgroep en hoop ik samen met hen dit werk nog lang voort te zetten, en misschien wel een keer iets over te vertellen in een zelfde soort gelegenheid(al is 1 oratie wel genoeg).

\section{Een woord van dank}

Dames en heren, het is tijd om af te sluiten en een drankje te nuttigen. Maar voordat wij dat gaan doen wil ik een paar woorden van dank uitspreken. Een eerste woord van dank is er voor het College van Bestuur en in het bijzonder het bestuur van de Faculteit der Psychologie en Neurowetenschappen voor het instellen van deze leerstoel. Dat ik die mag bekleden is een hele eer waarvoor ik me voor de volle honderd procent zal inzetten.

Dat ik zover ben gekomen, heb ik aan veel mensen te denken, die ik niet allemaal persoonlijk kan bedanken, maar een paar wil ik graag noemen.

Allereerst natuurlijk mijn begeleider, promotor en mentor Gerjo Kok. Jouw naam noemen tekent direct de moeilijkheid van het uitspreken van een dankwoord; waar moet ik beginnen? Steeds heb je me verrast in het vertrouwen dat je in me stelt, als student, toen je me aannam als promovendus, toen ik met je meeging naar psychologie als universitair docent maar feitelijk nog promovendus was en in jouw voordracht mij UHD te maken voordat ik daar mee bezig was en nu bijzonder hoogleraar terwijl ik dat voorlopig nog niet zag gebeuren. Ik ga en kan niet beschrijven wat ik van jouw geleerd heb, maar het heeft me erg ver gebracht en ik ben je daar dan ook zeer dankbaar voor. Jouw kennis van zaken, het gestructureerde denken en werken en grote discipline zijn een voorbeeld voor mij waarvan ik blij ben dat ik die nog iedere dag mag meemaken. Van de wijze waarop jij met een enkele rake zin en een vriendelijke lach mij tot bedaren kan brengen als ik me ergens druk om maak, hoop ik nog lang gebruik te maken. Je wijze en verstandige woorden. Veel, heel veel dank. 
Bart, ik noemde jouw rol al bij mijn andere grote hobby. Jouw wijsheid en liefde voor de opleiding van promovendi uit minder ontwikkelde landen, Afrika in het bijzonder, zijn een groot voorbeeld. Ik hoop dat we hierin nog lang samen kunnen optrekken. Ik leer nog zo veel van je.

Een groot woord van dank is er ook aan mijn promovendi. Zij doen het echte onderzoekswerk, waarvan ik dan profijt mag trekken, maar waar het vooral zeer plezierig mee samenwerken was en is. Inmiddels heb ik er 18 naar de eindstreep begeleid, waarvan nu 6 in mijn functie als promotor. Als de eis inderdaad is dat je minimaal 1 promovendus moet hebben afgeleverd per jaar dan heb ik in ieder geval voor de komende jaren al aan die eis voldaan. Van mijn huidige promovendi heeft niet iedereen een vermelding gekregen in mijn rede, dat ging gewoon niet, maar Birthe, Sanne, Feziwe, Mirjam jullie zijn me even dierbaar. Dank ook aan Fraukje, Karlijn en Loes; jullie betrokkenheid bij de begeleiding van promovendi maken de projecten nog beter.

En natuurlijk zijn er mijn overige collega's van mijn thuisbasis de capaciteitsgroep Arbeid en Sociale Psychologie. Steeds meer zijn we één club geworden. In een zeer prettige sfeer wordt er zeer veel en goed werk geleverd, op het gebied van onderzoek én onderwijs. Ik ben er trots op dat ik jullie voorzitter mag zijn en ik ben o zo blij met Mariella Muermans als mijn trouwe ondersteuner die heel goed nee kan zeggen, op momenten dat ik dat niet kan.

Ook collega's elders in het land en in het buitenland wil ik graag bedanken. Het maakt het werk nog veel waardevoller als je onderzoek direct in het veld wordt toegepast zoals in projecten met Theo Paulussen, Pepijn van Empelen en Hilde van Keulen bij TNO; met Hester de Melker en Liesbeth Mollema van het RIVM, en binnen verkeersveiligheid met mijn universitaire collega's in Hasselt Ellen Jongen, Kris Brijs en Tom Brijs en in het verkeersveld met Wilma Slinger van CROW, voorheen Kennisplatform verkeersveiligheid, Jan Vissers van DHV RoyalHaskoning en Gerard Kern van het regionaal orgaan verkeersveiligheid Gelderland Een woord van dank ook aan de collega's dichtbij, binnen de eigen faculteit inclusief die van de ondersteuning en Bureau Onderwijs, van wie ik er al veel zo lang ken en met wie ik zo plezierig samenwerk. En natuurlijk de capgroep Gezondheidsbevordering aan de overkant; daar begon het voor mij allemaal. De samenwerking met Ree Meertens is al lange tijd een heel groot plezier met veel wijze lessen van diep nadenken 
en goed methodologisch onderzoek doen en met Rik Crutzen hoop ik nog veel 'interesse' studies te doen. De contacten met Jascha, Anke, Nanne, Stef en Hein zijn me zeer dierbaar. En natuurlijk vergeet ik mijn oud collega's bij GVO en Psychologie Arjan Bos en Harm Hospers niet te noemen, naar elders gegaan maar nog steeds dichtbij.

Enkele jaren geleden heeft de Faculteit der Psychologie een naamsverandering ondergaan en heet zij nu de Faculteit der Psychologie en Neurowetenschappen, om zo recht te doen aan de enorme expertise die het in haar midden heeft als gaat om de Cognitieve Neurowetenschappen. Met de komst van hoogleraar Rainer Goebel in 2001 is er in korte tijd een onderzoeksgroep neergezet die binnen de cognitieve neurowetenschappen tot de absolute wereldtop behoort. De expertise is duizelingwekkend, gelukkig is er een aantal mensen dat mij op de been houdt; ik noemde al onze geweldige decaan Bernadette Jansma als het gaat om ERP onderzoek, maar in het bijzonder wil ik ook mijn steun en toeverlaat als het gaat om fMRI onderzoek, Vincent van de Ven, noemen. Veel dank. Je kennis van de neurowetenschappen maakt mij klein. Ik noem ook even Elia Formisano. We werken niet direct samen maar zijn enthousiasme en openheid is aanstekelijk en heeft mij altijd welkom doen voelen me in dit veld te begeven, al is het zijdelings en onder begeleiding. Hetzelfde geldt voor Fren Smulders, een wandelende EEG encyclopedie.

Dit werk kun je niet doen zonder een goede achterban thuis en in de privé-sfeer. Laat ik beginnen bij het begin, mijn ouders en mijn zus Selma en broer Jeroen. Ik kom uit een zeer warm nest; had het niet beter kunnen treffen. De warmte, steun en liefde die wij als kinderen hebben ontvangen bij alles wat wij deden was altijd groot en heeft ons zover gebracht, in het plezier voor de sport, studie en nu ons werk en gezinsleven. Dat ik echter nu pas hier sta, ruim twee jaar nadat ik de aanstellingsbrief tot bijzonder hoogleraar uit handen van onze rector Martin Paul ontving, hier in dit gebouw, heeft alles te maken met het overlijden van mijn vader. Hij zou trots zijn geweest en gelukkig heeft hij me dat ook nog persoonlijk kunnen laten weten. Op 5 september 2012 ontving ik de aanstellingsbrief in dit gebouw. Op de trappen voor dit gebouw heb ik hem direct gebeld. Dat gesprek zal mij altijd bij blijven. Hij was toen al doodziek, 9 dagen later overleed hij. We hebben op een zeer mooie manier afscheid kunnen nemen, maar het heeft even geduurd voordat ik deze stap wou en kon zetten. Ma, Selma en Jeroen. 
Jullie aanwezigheid hier, samen met jullie partners Sjoert en Jojanneke, betekent veel voor me. Selma en Jeroen, en ook Sjoert, alle vier hebben we de doctors titel. Ik heb vandaag de lat weer iets hoger gelegd.

Onder de aanwezigen hier vandaag zijn veel vrienden en goede bekenden. Erg leuk dat jullie gekomen zijn. Twee hele goede vrienden hebben mij bij gestaan bij belangrijke momenten in mijn leven: Maurice Alberts en René Lion. Zij waren paranimfen bij mijn promotie en getuigen bij mijn huwelijk. Fijn dat jullie hier ook weer bij zijn, helaas is er voor dit gebeuren geen ceremoniële rol voor jullie weggelegd. Maurice was de enige die de tekst van mijn rede mocht meelezen en heeft me van nuttige tips voorzien. Veel dank. Het is een goddelijk wonder dat we ons bijna wekelijks geouwehoer over voetbal over de telefoon en sms buiten de rede hebben kunnen houden. En als we het toch over mijn grote liefde voor de sport en sporten hebben, jongens en meiden van de fietsploeg, jullie maken het werken naar de zomervakantie toe altijd weer een genot.

En dan mijn gezin thuis. Lieve, lieve Miranda, Veerle, Niek en Dries. Wat wij met zijn vijven thuis hebben, is heel bijzonder. Daar ben ik jullie heel dankbaar voor. Het is een genot om 's avonds na een dag van hard werken door het mooie Zuid-Limburgse landschap naar huis te fietsen, wetende dat ik jullie daar aantref. Altijd dat warme welkom waardoor het werk direct naar de achtergrond verdwijnt en daar minstens een paar uurtjes blijft. Veerle, Niek en Dries, jullie zijn geweldig. Heel soms maken jullie me de kop gek, maar ook dan geniet ik van jullie.

Miranda, mijn steun en toeverlaat, ook jij komt uit een goed nest, met een voor mij zeer leuke schoonfamilie. Ik vertel mensen wel eens ons drukke schema dat wij thuis voeren, met drie sportende en muziek makende kinderen en allebei een druk werkend en sociaal leven. Het is een heel geplan maar gelukkig hebben we dat goed voor elkaar, met Jolanda en alle andere hulp, maar vooral omdat we het samen doen, en ik jou daar ook graag de leiding in geeft. Er was een tijd dat je regelmatig een bos bloemen van me kreeg, ook als je niet jarig bent zoals vorige week. Daar is de klad in gekomen laat ik daar vanaf vandaag maar eens weer mee beginnen. Ik hou van je.

Ik heb gezegd. 


\section{Referenties en bronnen}

Albarracín, D., Gillette, J. C., Earl, A. N., Glasman, L. R., Durantini, M. R., \& Ho, M.-H. (2005). A test of major assumptions about behavior change: a comprehensive look at the effects of passive and active HIV-prevention interventions since the beginning of the epidemic. Psychological Bulletin, 131(6), 856-97. doi:10.1037/0033-2909.131.6.856

Allport, G. W. (1985). The historical background of social psychology. In The handbook of social psychology (p. 5). New York: McGraw-Hill.

Bartholomew, L. K., Parcel, G. S., Kok, G., Gottlieb, N. H., \& Fernández, M. E. (2011). Planning health promotion programs: An Intervention Mapping approach (3rd ed.). San Francisco: Jossey-Bass.

Berkman, E. T., \& Falk, E. B. (2013). Beyond brain mapping: Using neural measures to predict real-world outcomes. Current Directions in Psychological Science, 22(1), 45-50. doi:10.1177/og63721412469394

Brijs, K., Ruiter, R., \& Brijs, T. (2009). Naar een evidence-based en doelgroepspecifieke verkeerseducatie. In Jaarboek Verkeersveiligheid (pp. 92-100). Mechelen: Vlaamse Stichting Verkeersveiligheid.

Bruin, M. de, Viechtbauer, W., Schaalma, H. P., Kok, G., Abraham, C., \& Hospers, H. J. (2014). Standard Care Impact on Effects of Highly Active Antiretroviral Therapy Adherence Interventions. Archives of Internal Medicine, 170(3), 240-250.

Buunk, A. P., \& Vugt, M. van. (2013). Applying social psychology: From problems to solutions (2nd ed.). London: Sage.

Centraal Bureau voor de Statistiek. (2014). Fors minder verkeersdoden in 2013. Retrieved from http://www.cbs.nl/NR/rdonlyres/FAC6EA11-7889-4DF4-8AC81EADFA3119E8/o/pb14no25.pdf

Chein, J., Albert, D., O’Brien, L., Uckert, K., \& Steinberg, L. (2011). Peers increase adolescent risk taking by enhancing activity in the brain's reward circuitry. Developmental Science, 14(2), F1-10. doi:10.1111/j.1467-7687.2010.01035.x

Eberl, C., Wiers, R. W., Pawelczack, S., Rinck, M., Becker, E. S., \& Lindenmeyer, J. (2013). Approach bias modification in alcohol dependence: Do clinical effects replicate and for whom does it work best? Developmental Cognitive Neuroscience, 4, 38-51. doi:doi:10.1016/j.den.2012.11.002

Eisenberger, N. I., Lieberman, M. D., \& Williams, K. D. (2003). Does rejection hurt? An FMRI study of social exclusion. Science (New York, N.Y.), 302(5643), 290-2. doi:10.1126/ science.1089134

Falk, E. B. (2010). Communication Neuroscience as a Tool for Health Psychologists. Health Psychology, 29(4), 355-357. doi:10.1037/a0020427

Falk, E. B., Berkman, E. T., \& Lieberman, M. D. (2012). From neural responses to population behavior: neural focus group predicts population-level media effects. Psychological Science, 23(5), 439-45. doi:10.1177/0956797611434964 
Gardner, M., \& Steinberg, L. (2005). Peer influence on risk taking, risk preference, and risky decision making in adolescence and adulthood: an experimental study. Developmental Psychology, 41(4), 625-35. doi:10.1037/0012-1649.41.4.625

Giedd, J. N., Blumenthal, J., Jeffries, N. O., Castellanos, F. X., Liu, H., Zijdenbos, a, ... Rapoport, J. L. (1999). Brain development during childhood and adolescence: a longitudinal MRI study. Nature Neuroscience, 2(10), 861-3. doi:10.1038/13158

G-J. Y. Peters. (2014). A practical guide to effective behavior change: How to identify what to change in the first place. The European Health Psychologist, 16(5), 142-155.

Godin, G., Gagnon, H., Alary, M., Levy, J. J., \& Otis, J. (2007). Advancing knowledge The degree of planning : an indicator of the potential success of health education programs, XIV(3), 138-142

Green, L. W., \& Kreuter, M. W. (2005). Health promotion planning: An educational and ecological approach (4th ed.). New York: Mc Graw Hill Professional.

Hofmann, W., Friese, M., \& Wiers, R.W. (2008). Impulsive versus reflective influences on health behavior: a theoretical framework and empirical review. Health Psychology Review, 2(2), 111-137. doi:10.1080/17437190802617668

Kessels, L.T.E., \& Ruiter, R. A. C. (2012). Eye movement responses to health messages on cigarette packages. BMC Public Health, 12, 352. doi:10.1186/1471-2458-12-352 Kessels, L. T. E., Ruiter, R. A. C., Brug, J., \& Jansma, B. M. (2011). The effects of tailored and threatening nutrition information on message attention. Evidence from an eventrelated potential study. Appetite, 56(1), 32-8. doi:10.1016/j.appet.2010.11.139

Kessels, L. T. E., Ruiter, R. A. C., \& Jansma, B. M. (2010). Increased attention but more efficient disengagement: neuroscientific evidence for defensive processing of threatening health information. Health Psychology, 29(4), 346-354. doi:10.1037/ aoo19372

Kessels, L. T. E., Ruiter, R. A. C., Wouters, L., \& Jansma, B. M. (2014). Neuroscientific evidence for defensive avoidance of fear appeals. International Journal of Psychology: Journal International de Psychologie, 49(2), 80-8. doi:10.1002/ijop.12036

Kok, G. (2014). A practical guide to effective behavior change. The European Health Psychologist, 16(5), 156-170.

Kok, G., Lo, S.-H., Peters, G.-J. Y., \& Ruiter, R. A. (2011). Changing energy-related behavior: An Intervention Mapping approach. Energy Policy, 39, 5280-5286. doi:10.1016/j.enpol.2011.05.036

Kok, G., \& Ruiter, R. A. C. (2014). Who has the authority to change a theory? Everyone! A commentary on Head and Noar. Health Psychology Review, 8(1), 61-64. doi :10.1080/17437199.2013.840955

Kok, G., Schaalma, H., De Vries, H., Parcel, G., \& Paulussen, T. (1996). Social psychology and health education. In W. Stroebe \& M. Hewstone (Eds.), (Vol. 7, pp. 241-282). Chichester, UK: John Wiley \& Sons Ltd. 
Kok, G., Schaalma, H., Ruiter, R. A. C., Van Empelen, P., \& Brug, J. (2004). Intervention Mapping: A Protocol for Applying Health Psychology Theory to Prevention Programmes. Journal of Health Psychology, 9(1), 85-98. doi:10.1177/1359105304038379

Kok, G., van Essen, G. A., Wicker, S., Llupià, A., Mena, G., Correia, R., \& Ruiter, R. a C. (2011). Planning for influenza vaccination in health care workers: an Intervention Mapping approach. Vaccine, 29(47), 8512-9. doi:10.1016/j.vaccine.2011.09.008

Mevissen, F. E. F., Meertens, R. M., Ruiter, R. A. C., \& Schaalma, H. P. (2010). Testing implicit assumptions and explicit recommendations: the effects of probability information on risk perception. Journal of Health Communication, 15(6), 578-89. doi:1 $0.1080 / 10810730.2010 .499591$

Mevissen, F. E. F., Ruiter, R. A. C., Meertens, R. M., \& Schaalma, H. P. (2010). The effects of scenario-based risk information on perceptions of susceptibility to Chlamydia and HIV. Psychology \& Health, 25(10), 1161-74. doi:10.1080/08870440903055901

Nederland, S. A. (2014). Soa Aids Nederland. Retrieved from http://soaaids.nl/nl/ lang-leve-de-liefde-best-beoordeelde-lespakket

Paus, T. (2005). Mapping brain maturation and cognitive development during adolescence. Trends in Cognitive Sciences, 9(2), 60-8. doi:10.1016/j.tics.2004.12.008

Peters, G.-J. Y., de Bruin, M., \& Crutzen, R. (2013). Everything should be as simple as possible, but no simpler: towards a protocol for accumulating evidence regarding the active content of health behaviour change interventions. Health Psychology Review, 1-14. doi:10.1080/17437199.2013.848409

Peters, G.-J. Y., Ruiter, R. a C., \& Kok, G. (2013). Threatening communication: a critical re-analysis and a revised meta-analytic test of fear appeal theory. Health Psychology Review, 7(Suppl 1), S8-S31. doi:10.1080/17437199.2012.703527

Rijksinstituut voor Volksgezondheid en Milieu. (2014a). Een gezonder Nederland. Retrieved from http://www.eengezondernederland.nl/

Rijksinstituut voor Volksgezondheid en Milieu. (2014b). Volksgezondheid Toekomst Verkenning, Nationaal Kompas Volksgezondheid. Retrieved from http://www. nationaalkompas.nl/gezondheidsdeterminanten/leefstijl/seksueel-gedrag/

Ross, V., Jongen, E., Brijs, T., Ruiter, R., Brijs, K., \& Wets, G. (2014). The Relation Between Cognitive Control and Risky Driving in Young Novice Drivers. Applied Neuropsychology: Adult, (March 2014), 1-12. doi:10.1080/23279095.2013.838958

Ross, V., Jongen, E. M. M., Wang, W., Brijs, T., Brijs, K., Ruiter, R. a C., \& Wets, G. (2014). Investigating the influence of working memory capacity when driving behavior is combined with cognitive load: An LCT study of young novice drivers. Accident; Analysis and Prevention, 62, 377-87. doi:10.1016/j.aap.2013.06.032

Ruiter, R. A. C., Abraham, C., \& Kok, G. (2001). Scary warnings and rational precautions: A review of the psychology of fear appeals. Psychology and Health, 16, 613-630. doi:10.1080/08870440108405863 
Ruiter, R. A. C., Kessels, L. T. E., Peters, G.-J. Y., \& Kok, G. (2014). Sixty years of fear appeal research: current state of the evidence. International Journal of Psychology: Journal International de Psychologie, 49(2), 63-70. doi:10.1002/ijop.12042

Ruiter, R. A. C., Massar, K., Vugt, M. van, \& Kok, G. (2012). Applying social psychology to understanding social problems. In A. Golec de Zavala \& A. Cichocka (Eds.), Social psychology of social problems: The intergroup context. (pp. 337-362). New York: Palgrave Publishers.

Schaalma, H. (2007). Met de voeten in de klei (inaugurele rede). Maastricht: Universiteit Maastricht.

Schaalma, H., \& Kok, G. (2009). Decoding health education interventions: the times are a-changin'. Psychology \& Health, 24(1), 5-9. doi:10.1080/08870440801995802

Steinberg, L. (2007). Risk Taking in Adolescence: New Perspectives From Brain and Behavioral Science. Current Directions in Psychological Science, 16(2), 55-59. doi:10.1111/ j.1467-8721.2007.00475.x

Steinberg, L. (2009). Reconciling the Complexity of Human Development With the Reality of Legal Policy. American Psychologist, 64(7), 601-604. doi:10.1037/a0017246

Ten Hoor, G. a, Peters, G.-J. Y., Kalagi, J., de Groot, L., Grootjans, K., Huschens, A., ... Kok, G. (2012). Reactions to threatening health messages. BMC Public Health, 12, 1011. doi:10.1186/1471-2458-12-1011

Toppenberg, H. L., Bos, A. E. R., Ruiter, R. A. C., Wigboldus, D. H. J., \& Pryor, J. B. (n.d.). HIV-related stigma in social interactions: Approach and avoidance behavior in a virtual environment. European Journal of Social Psychology.

Tybur, J. M., Bryan, A. D., \& Caldwell Hooper, A. E. (2012). An Evolutionary Perspective on Health Psychology: New Approaches and Applications, 10(5), 855-867.

Van Achterberg, T., Huisman-de Waal, G. G. J., Ketelaar, N. a B. M., Oostendorp, R. a, Jacobs, J. E., \& Wollersheim, H. C. H. (2011). How to promote healthy behaviours in patients? An overview of evidence for behaviour change techniques. Health Promotion International, 26(2), 148-62. doi:10.1093/heapro/daq050

Wetenschappelijke Raad voor het Regeringsbeleid. (2014). Met kennis van gedrag beleid maken. Amsterdam: Amsterdam University Press.

Wiers, R. W., Gladwin, T. E., Hofmann, W., Salemink, E., \& Ridderinkhof, K. R. (2013). Cognitive Bias Modification and Cognitive Control Training in Addiction and Related Psychopathology: Mechanisms, Clinical Perspectives, and Ways Forward. Clinical Psychological Science. doi:10.1177/2167702612466547 
